\title{
Populism, Nationalism, and Party Politics
}

\author{
Sherrill Stroschein* \\ University College London, London, United Kingdom \\ *Corresponding author. Email: s.stroschein@ucl.ac.uk
}

Acknowledgements: I am grateful to conversations with Zsuzsa Csergö, Erin Jenne, and Jessica Pisano on the literature on nationalism and populism and to Stephen Deets and two anonymous reviewers for comments on an earlier draft of this piece.

\begin{abstract}
:
Recent political events have forced an examination of ideologies of populism and nationalism in politics. In this review piece, I provide an overview of literature on the post-2016 political context to indicate why analysts might have been surprised by the rise of identity-based politics. A full understanding of identity-based parties requires a focus on both the forms by which they navigate electoral and party systems, and the content of their rhetorical appeals to publics. I consider the electoral and party systems literature, and indicate some reasons that majoritarian electoral systems appear more likely to foster the dominance of identity-based politics. In such systems, large parties might become weaponized by extremist elements, and lack the potential for checks from new parties. In addition, presidential systems lack a mechanism for no confidence votes, and thus might also have weak checks on an extremist executive. In terms of content, populism and nationalism might draw differing boundaries to include or exclude perceived elites. However, they can otherwise align in terms of their stances against Others, as well as against individualistic or technocratic stances that may fall under the label of "liberalism." Nationalism and populism are not simply ideologies, but can be used as strategies by elites who know how to successfully deploy these mobilizing rhetorical appeals.
\end{abstract}

Keywords: Parties, Party Systems, Nationalism, Nationalist, Populism, Populist, Ethnic, Ethnic Parties.

Recent political events have brought an increased interest in the ideologies of populism and nationalism in politics. In particular, the 2016 election shakeups in the US and the UK have focused attention on whether the "normal" models of politics in those countries need to be re-examined. The field of nationalism studies, which had become largely used to thinking of the West as a model of civilized or "civic" nationalism (Greenfeld 1993, Snyder 2000), began to realize that their work on ethnicity and nationalism could now apply to the West. Theories and ideas that had emerged from research on nationalism in Eastern Europe and the former Soviet Union since the 1990s became useful to understand some of these party developments in Western countries. At the same time, those who had researched populism and right-wing parties (Mudde 2004, 2007, Stanley 2008, Vasiliopolou 2009) found their ideas suddenly in high demand in trying to make sense of these newly-successful political movements. 
In terms of party politics, both nationalism and populism behave in similar ways in electoral and party systems, as producing identity-based parties. When discussing party politics, researchers of populism and nationalism are often talking about very similar things, but using different language. There has been some useful research on potential alignments in the content of nationalism and populism (Tismaneanu 1998, Jenne 2018, Bonikowski et al 2019, Müller 2019, Wimmer 2019). However, the way in which identity-based parties rise, fall, and navigate within electoral and party systems has been less well-examined. In order to understand their impact on politics and democracies, it is important to understand the system dynamics through which these parties come to and remain in power. In this review piece, I outline a survey of electoral and party systems literature, and indicate some reasons that majoritarian electoral systems appear more likely to foster the dominance of such parties. In addition, presidential systems, which lack a mechanism for no confidence votes, might also have weak checks on an extremist executive. But first, I provide a brief sketch of the literature on recent party developments, to set this discussion in context. The second section considers the party and electoral system dynamics in which identity-based parties operate, outlining the potential pitfalls of majoritarian and presidential systems, and the last section considers the points of alignment in the content of populism and nationalism as ideologies - and how they can both be used as political strategies by elites.

\section{What Has Been Going on Since 2016?}

In early 2016, Katherine Cramer published a book titled The Politics of Resentment: Rural Consciousness in Wisconsin and the Rise of Scott Walker. In contrast to much survey- and quantitative-heavy research in the field of American politics, Cramer conducted an ethnographic study in which she listened to rural Wisconsin voters talk about politics. She found that these rural voters, who seemed to be voting for then-Governor Walker in spite of their economic interests, were instead guided by feelings of injustice and resentment. These sentiments included a moral judgement, that "deserving" peoples in rural areas were receiving less political attention than "undeserving" individuals in urban areas. The left-right configuration of politics, based on an assumption of how people would vote according to material interest, was a problematic assumption in trying to understand what motivated these voters. A few months later, Donald Trump won the 2016 election, buoyed partly by an increase in votes in states like Wisconsin - which had been assumed to deliver a Democratic vote and which did not. Cramer had found something many others had missed, an emphasis on identity and cultural resentment.

A few others also saw these trends. In a book published in 2016, Achen and Bartels also saw evidence of a trend of political polarization in the US, based on a comprehensive array of statistical 
studies. Their evidence revealed the role of identity and culture as sources of political polarization in the US, a setting in which the moderate center disappears from politics. In contrast to the longstanding Downs' median voter theorem, which posits that majority elections in districts will produce moderation, they found instead a strong division between parties, and great distance between them - a dynamic discussed further in the section below. Based on a broad set of empirical findings, Achen and Bartels show how strong loyalty to one party identity can create a bifurcated electorate in majoritarian electoral systems, a situation reflected in increased polarization in the United States. In psychological terms, voting on a party identity is a simple act that removes the effort to process information (35-36). In a situation in which tired individuals are navigating complex political information, identity voting can be an attractive shortcut. Observing similar identity voting in the US, Mason (2018) describes these new polarized conditions as "identity based democracy."

The study of values and culture had not been entirely absent from the study of US politics up to this point, though it certainly was subdued. Before the left-right economic spectrum had emerged as a dominant assumption much of this work, Inglehart (1971) had examined a role for values in politics with the use of survey responses. Inglehart argued that once modern and stable polities have moved beyond the attainment of basic economic needs, they can develop postmaterialist values that are more expressive and less materialist. Political action could thus move off of the left-right economic spectrum into the area of culture, values, and identity. Inglehart was quick to react to the 2016 US election. In a 2017 piece written with Norris, his earlier insights are woven into a discussion of the post-2016 US environment. This adjusted argument outlines that under conditions of inequality, voters with insecure circumstances might exhibit an "Authoritarian Reflex" - by which they might support a strong leader and become wary of cultural change such as immigration (Inglehart and Norris 2017).

There is a direct link between this automatic party identity voting observed by Achen and Bartels (2016), Cramer (2016), and Mason (2018) and the populist notion of "silent majorities" (Canovan 1999, Mudde 2004), waiting to be mobilized to express their concerns on changing circumstances - both economic and cultural. After years of being marginal in mainstream party literature, the dynamics of identity parties have returned with a vengeance to provide some crucial explanatory insights into current American politics. Identity politics is also a strong part of the Brexit debates in the United Kingdom, where pro- and anti-Brexit identities cut across party lines and have increased fragmentation within the Conservative and the Labour party (Goodwin and Heath, 325, 331). Similarly, continental Europe has seen significant victories for extremist and anti-establishment parties in elections. The old systems are being shaken. 
This resurgence of identity in party politics has followed on what many had understood to be a decline in party membership and participation, as well as in voter turnout. According to the cartel party thesis (Katz and Mair 2009), West European parties had become hollowed-out institutions that distributed the spoils of politics among a few, and with less genuine participation from new members. Western democracies in particular were seen by Mair (2013) as exhibiting a democratic "void" due to this hollowing out of parties. Voters frustrated by these moribund organizations might be likely to turn their attention to new challenger parties (Katz and Mair 2009, 2018, Kreisi 2014). Protest voting, as wanting to "throw out the bums" might also take the form of voting for completely new parties, bringing complete changes to party systems in Europe (PopEleches 2010, Sikk 2011, O’Dwyer 2014, Haughton and Deegan-Krause 2015).

At first glance, the decline of established parties might appear to counter a notion of voting on the basis of identity. But an examination of the recent US and UK context reveals that automatic identity voting can be a replacement for actual engagement, a substitute for considering actual issues (Achen and Bartels 2016, Levy 2017). Although a recent increase in the visibility of identity is a common denominator across several systems, the causes behind it may differ by country. Immigration has been a common identity focus across these countries, but the content of discussion differs on different sides of the Atlantic. An additional difference is that in Europe, the European Union has become a target for some of these parties, as a set of largely bureaucratic and technocratic institutions devoid of identity (Muller 2014, Pirro 2018, Wimmer 2019). The romance of populism, as noted by Canovan (1999) and Kaltwasser (2014), provides a means to compensate for the boring pragmatism of the technocratic structures of the EU.

We now know what the recent literature thinks is happening with identity-based parties. But to better understand why these parties are successful, and when and where success might vary, we must turn to a more in-depth discussion of the dynamics of electoral and party systems.

\section{Identity-based Parties in Electoral and Party Systems}

The identity-based voting outlined in the recent literature discussed above has several points of resonance with previous work on ethnic parties, and with older literature on party systems. The almost automatic identity-based voting behind polarized systems reflects Horowitz' (1985) notion of the "census voting" for ethnic parties that can produce ethnic outbidding. In outbidding, voting along identity lines tends to produce more extreme politics within groups. This is because potential leaders can only obtain votes within one ethnic group, and are thus likely to compete for leadership on platforms that advance the interests of that group. As each ethnic group trends toward more extreme stances, the center of the system falls away and polarization emerges. 
Horowitz finds this potential mechanism to be so dangerous that he finds ethnic parties to be problematic.

Even before the 2016 election, the dynamics within the US Republican party that had produced Donald Trump as a presidential candidate had led to concerns by those familiar with outbidding, and the potential for identity-based appeals to foster extremism (Saideman 2015). Polarization and identity-based voting also finds echoes in Sartori's discussion of polarized pluralism (1976), discussed further below. But in spite of these useful ideas, the general field of Comparative Politics has had some blind spots with regard to the potential emergence of identity-based parties, and the way in which identity might become a resource for elites.

In this field, parties have been understood to emerge from cleavages in society, as functional means to represent these societal interests in politics (Almond and Coleman 1960, Lipset and Rokkan 1967, Sartori 1976). This rather sociological understanding of party origins takes them as sincere expressions of identity-based cleavages. But this view is less useful to explain how parties might rise and fall, while cleavages are relatively stable. The notion that leaders might be poised to increase or decrease the salience of identity cleavages, or boundaries, (Tilly 2003, Stroschein 2016) does not figure in this approach. This "sincere-cleavages" view is one reason the field of Comparative Politics has had some trouble with understanding how populism or nationalism can be useful strategies by leaders to launch or strengthen identity-based parties.

However, the rational choice grounding for many studies of voting behavior do not fare much better in this vein. Much of this literature assumes that the choices of voters are based on their sincere preferences. In this literature, the content of these preferences are exogenous, or external to the voting process. Voters simply have certain goals that they bring to the voting process, and choose accordingly on the ballot. But voters might also be reacting to the rhetoric of would-be elites, meaning that their preferences are formed in the course of a long electoral process. Contrary to the assumption of exogenous preferences, preferences might be formed as an endogenous part of the process. Theories of elite manipulation, developed in the nationalism literature, might be a better way to understand the way in which voters encounter identity-based parties.

These blind spots in Comparative Politics might indicate why much of the field of Comparative Politics has had some difficulty in explaining the increase of parties with a populist style, or the infusion of existing parties with this style. Scholars of both nationalism and populism are more prepared to consider the ways in which these ideologies might be cynically deployed as successful political strategies, as discussed in the section below. The Comparative Politics literature has quite simply been rather idealistic about parties, as functional channels of interest in democracies (Almond and Coleman 1960). As outlined by Sartori, parties are understood to be 
"part" of the polity whole, logical elements of a pluralist political order and thus of democracies (Sartori 1976, 3). Parties are understood to provide a crucial link between citizens and governments, as a means to translate preferences of the public into power or policy (Stokes 1999). The development of parties and party systems in democracies tends to be viewed through a pluralist lens of competition and a rotation in and out of power-mechanisms necessary to hold governments accountable (Dahl 1971, Schmitter and Karl 1993, Rosenbluth and Shapiro 2018). ${ }^{1}$ In order to understand how these dynamics might play out in less ideal ways, it is useful to start with an examination of the electoral systems by which these parties come to power.

\section{Implications of Majoritarian versus Proportional Electoral Systems}

Competition and power are shaped via the defining rules of electoral systems. The number of parties we expect to see in a party system is strongly dictated by electoral systems. ${ }^{2}$ The most common form of majoritarian systems are first-past-the post systems (FPTP) in single-member districts, or SMD (Reynolds et al 2005), and are used in the US and the UK. These FPTP in SMD systems tend toward two larger parties - while proportional representation systems tend to produce more parties (Duverger 1954, cited in Sartori 1994). The reason for fewer parties in this type of majoritarian system lies in the mechanisms of voting. Majoritarian systems in a district in which one candidate is to be elected will focus voter attention on the strongest candidates, producing support for the largest parties. ${ }^{3}$

Much of the work on majoritarian systems has assumed that the available pool of voters lie across a normal statistical distribution, in terms of left-right preferences on the relation of government to markets. The strongest candidates are thus expected to vie for support from the large, moderate pool of voters in the middle of this economic-based distribution. This mechanism for moderation in majoritarian systems comprises the foundation of the Downsian median voter theorem mentioned above - a stalwart premise of voting in majoritarian systems (Downs 1957, Achen and Bartels 2016, 23-25). However, these predicted dynamics go awry if voters are no longer moderate on this left-right economic spectrum, and no longer tending toward the middle of the distribution. What if voters might instead be polarized between both sides, with no moderate middle, as in the currently polarized US mentioned above (Achen and Bartels 2016, Mason 2018)? Or, what if the main spectrum of cleavage is no longer usefully represented as left-right? Changing these base assumptions implies that the Downsian scenario would not apply, and instead smaller parties or newcomers might also attract voters in certain (or many) districts.

The large parties that have dominated majoritarian systems tend to be understood as umbrella organizations that incorporate a broad range of interests (Rosenbluth and Shapiro 2018), 
with a focus on the left-to-right spectrum as a priority. Identity-based parties have been completely absent from these assumptions as applied to the analysis of majoritarian FPTP systems. In fact, identity parties have been rendered invisible in much of the general work on parties and party systems, or treated as entities that should fall away as part of a modernizing process of "party system nationalization" (Caramani 2004, Chibber and Kollman 2004). At best, potential ethnic voters in majoritarian systems can only band together as a group under a party umbrella, such as the Congressional Black Caucus in the US. But recent politics in the US and the UK shows that elites using populist or nationalist appeals can hijack these larger party structures, moving them to an ideological extreme. Contrary to the vision of Rosenbluth and Shapiro (2018), these extreme appeals may not be quashed by the broad structure of the party - instead, with an extremist at the helm, the size of the party might become weaponized to advance these extreme positions. Such dynamics have now appeared with the Trump administration in the US and the chaotic Tory party pursuit of Brexit in the UK. The parties are also fragmenting internally, as more moderate elements try to wrest control of the careening party vehicle from the more extremist elements, with volatile implications.

Majoritarian, FPTP systems are susceptible to these dynamics due to their emphasis on efficiency over representation (Diamond 1993, Sartori 1994, Lijphart 1994). The reductive effect of the FPTP voting structure in single-member-districts means that it is very difficult to start a new party, or to form a challenger to two large parties. In the proportional systems discussed below, dissenting, moderate elites could more realistically form a new party, from which they could challenge extremists. But the formation of successful new parties is extremely difficult in a majoritarian system. Fewer parties mean fewer coalition veto points at which government policy can be blocked. In contrast, proportional representation systems have more of these points through more parties and coalition politics, to which I now turn.

Proportional representation (PR) electoral systems are understood to represent more particular interests via a number of small parties - including identity parties. In PR systems, voters cast their votes for parties rather than for candidates on the ballot. The vote results and seat distributions in parliament reflect the percentages received for each party. ${ }^{4}$ Proportional systems thus emphasize a diversity of representation among different groups. These systems may involve country-wide voting on the same ballot, or may break the country into regional ballots. Even with regional PR balloting, the territory from which votes might be drawn tends to be larger than in majoritarian FPTP's districts. Because votes are gathered from across a wider territory, identitybased parties can pick up their support across varied demographics in the state, making proportional representation systems a favorite for those who wish to facilitate the emergence of ethnic or other identity-based parties. Even small identity-based parties can become key players in proportional 
representation systems, because they can form and leave coalitions. This "kingmaker" aspect of coalition politics gives small parties potential power beyond their size.

Sartori thus defines "relevant parties" by their functions, rather than size - whether they might have the potential to form coalitions, or whether they can blackmail other parties $(1976,122$ 23). ${ }^{5}$ Using Sartori's "coalition or blackmail potential" definition for relevant parties, it becomes clear that small ethnic, nationalist, or populist parties can be very relevant in European systems. The Greens are also rising in relevance, as they are rapidly emerging as a moderate counter-force to some of these identity-based parties. Continental Europe tends to have a high prevalence of proportional representation systems, and the dynamics of veto points in coalition making and breaking have provided strong political drama in the recent elections.

Strong regional parties might also produce the potential for some of these dynamics. In spite of the UK's majoritarian FPTP system with single-member districts, unique regional and identity parties in the UK has meant that small parties can have significant coalition and blackmail potential in that system. For example, the Liberal Democrats compete directly with Tories or Labour in several districts across the UK, and were in coalition with the Tories between 2010-2015. The Democratic Unionist Party, a Protestant party from Northern Ireland, has served in a coalition with the Tories from 2017 to the present writing. And the Scottish National Party currently reigns dominant in Scotland, and is the third largest party in the UK House of Commons, after the Tories / Conservaties and Labour. ${ }^{6}$ We might classify the UK as a majoritarian system with a dominance of two main parties, but with some notable regional parties. In spite of recent volatile party politics in the UK, it has proven difficult to successfully establish a completely new party - as demonstrated by the weak showing of the Women's Equality Party and the 2019 case of The Independent Group / Change UK.

As mentioned above, the presence of fewer parties and thus fewer veto points in majoritarian systems can make majoritarian systems vulnerable to the potential takeover of a large party by extremist elements. These electoral system effects will naturally interact with governmental structures: ie, whether a system is presidential or parliamentary (Lijphart 1993). Continental Europe features a number of countries with PR electoral systems and parliamentary, rather than presidential, governmental structures. Parliamentary government increases the potential impact of one crucial veto point: the option of a parliamentary no-confidence vote in the government and the potential for early elections (Sartori 1994). Thus, we might understand systems with both PR and parliamentary structures as having some potentially strong veto points. A governing party often must negotiate with other parties and could be subject to an early vote of no confidence.

But surely the UK has some veto points available in its parliamentary structure? Well, this aspect is no longer straightforward. In 2011, there was enough mutual mistrust by the Tories and the 
Liberal Democrats regarding their coalition that they passed the Fixed-Term Parliaments Act (FPTA). The FPTA placed serious constraints on the ability of parliaments to hold a vote of no confidence and call for early elections, thus radically changing the no confidence vote / early elections provisions that are part of a classic parliamentary structure. Such a strong change to the governing rules by a parliamentary vote was enabled by the country's lack of a written constitution, and the perceived dominance of parliamentary sovereignty. ${ }^{7}$ No confidence votes remain possible, just more difficult and thus this potential veto check on an extreme executive has been weakened.

Presidential systems have fixed terms, so are not subject to this type of strong veto point. A president with a weak mandate will thus be able to carry out the term unchallenged. The main veto points in the US presidential system have been understood to come from the Congress / legislative branch, and from the courts. But in practice, these checks require that the legislative branch might wish to serve as a check the executive, which has only become the case following the 2018 midterm elections. In addition, the Trump administration's fast pace of implementing policy has proven a successful strategy to reduce potential challenges from the judicial branch, which is very slowmoving relative to this pace of change (Stroschein 2017). The majoritarian electoral system, combined with the presidential governance system, does not appear to be very successful in providing veto point blocks on an extremist executive.

This overview of the mechanics of electoral and party systems has set the context within which identity-based parties might operate. I now turn to these dynamics.

\section{Identity-based Parties and System Fragmentation}

As outlined in the first section, our understanding of ethnic parties has included their potential for polarizing dynamics, via the mechanism of outbidding (Horowitz 1985). In outbidding, ambitious elites within each group have an incentive to make more extreme appeals to win votes. The outbidding mechanism is the opposite of the Downsian median voter theorem discussed above. Instead of converging toward the moderate center of a system, the center becomes empty as parties spin away from each other. The result is "stable parties, unstable politics" (Horowitz 1985, 348) and he finds banning ethnic parties to be preferable to dangerous outbidding.

Outbidding has been applied to understand recent politics in the US (Saideman 2015), but also makes sense when applied to the dynamics of populist parties observed in Europe. Some recent successes of some populist parties on the Right has led to some arguments on the Left that they should emulate a populist rhetoric, or jump on the populist bandwagon. For example, some parties on the Left have begun to perceive that they might also invoke an anti-immigration narrative, to better compete with these parties. The fact that such a strategy is being considered demonstrates a 
source of discursive power for these parties. As explained by Jenne, "ethnopopulists" can thus shift a national discourse to include their claims in spite of their size (Jenne 2018: 547).

This notion is worrying to those who have studied populism. As noted by Mudde (2019), any attempt to outbid the outbidders on their own defined ground is a weak strategy - it merely legitimizes their narrative and can thus increase their support. Instead, Mudde argues that parties wishing to compete with an outbidding narrative must develop a more positive and constructive counter-narrative. If a social democratic party wishes to counter a populist, anti-immigrant narrative, it should propose to rebuild the social democratic policies that have been eradicated since the 1980s and recent austerity (Mudde 2019).

In addition to this legitimation of extreme views, efforts to deploy extremist rhetoric can fragment party systems in dangerous ways, by empowering only extreme ideologies and weakening moderate ideologies at the center. While Horowitz focuses on two parties in outbidding opposition, more parties can be involved in these polarizing dynamics, in the multiparty systems that emerge in PR electoral systems. As noted above, these dynamics are well-traced by Giovanni Sartori. His 1976 book Parties and Party Systems documents a system type of "polarized pluralism," in which PR systems with more than five or six parties will compete for voter attention. In the course of this competition, they vie to set themselves in opposition to each other, moving further from each other and leaving the moderate center vacant (131). These centrifugal party dynamics have been used to explain how Weimar Germany's polarized party system could produce the rise of an extremist leader such as Hitler (Sartori 1976, Berman 1997).

Sartori's 1976 insights on these dynamics also include a means to systematically map identity-based parties. He envisions a spectrum of potential cleavages that goes well beyond the typical left-right dimension - it also includes an axis for "authoritarian" versus "democratic," p. 336. This notion of a more nuanced party spectrum was further developed by Herbert Kitschelt in 1992. Kitschelt's framework for mapping parties in relation to each other includes an identity-based axis with a line he labels "libertarian / cosmopolitan" versus "authoritarian / particularist" (p. 17). Given that a number of parties in the emerging political systems of Eastern Europe portrayed themselves as based on ethnic / national or religious identity in the 1990s, Kitschelt understood the left-right dimension alone to provide an impoverished portrayal of where parties might lie in relation to each other. An added identity and culture component improves on our ability to categorize parties in relation to each other across more than one axis, especially important in the contemporary context.

Having now examined the electoral and party system dynamics in which identity-based parties might operate, it is now important to understand their ideological content, and how this might interact with their success. 


\section{Nationalism and Populism as Similar Ideologies and Strategies ${ }^{8}$}

Are nationalism and populism in fact two words describing the same phenomenon? Have Western scholars used "populism" to describe events in their countries, because "nationalism" has been a term they have reserved for the East (Kostovicova 2019)? Indeed, the two ideologies seem to become intertwined when examined closely. Both see ideas of liberalism, or a focus on the individual, as in opposition to their romance of the collective, the group. Both see themselves as opposed to the technocratic removal of policy from the political sphere. This section outlines how we might understand populism and nationalism as similar ideologies and strategies in a review of the literature.

Mudde defines populism as a "thin-centered ideology" resting on a distinction between a "corrupt" elite and the people. This distinction invokes a normative premise, that politics should be an expression of the will of the people - the "general will" in a Rousseauian collective sense. For Mudde, the opposites of populism are elitism and pluralism $(2004,543 ; 2007,23)$. We are at first in a quite different territory from nationalism. As expressed in uprisings against the Hapsburgs from the 1840s onwards, nationalism served as a means to make the people feel a part of the same political community as "their" elites (Kann and David 1984). Nationalism produces a common national boundary around elites and masses, and an opposition to those outsiders of other groups.

In addition, contemporary populism is not portrayed as direct participation, but rather as comprised of a "silent majority:" a person who is "the hard-working, slightly conservative, lawabiding citizen , who, in silence but with growing anger, sees his world being 'perverted' by progressives, criminals, and aliens" (Mudde 2004, 557-58, also in Canovan 1999, 5). Populist appeals are made by agents in an attempt to mobilize these publics (Stanley 2008, 98).

As the content of these silent majorities might vary, populist parties may be either left or right. Rather than a clear and coherent ideology on a left-right material spectrum, the operative aspect of populism is a divide between a corrupt elite and the people (Gidrón and Bonikowski 2013, Rooduijn and Akkerman 2015, Bonikowski et al 2019). The flexibility of populism in terms of the materialist left-right spectrum of politics can help explain why both the Conservative and the Labour party in the United Kingdom are fragmenting over the populist issue of Brexit. Populism and nationalism can both easily cut across left-right lines.

The notion of "the nation" is rather subjective in the nationalism literature. It is perhaps best phrased as an "imagined political community," in essence, a group of people who believe they belong together (Anderson 1983, 6). As famously stated by Gellner (1983), nationalism is the notion that the nation and the state should be congruent. Because nations and states are inevitably mixed 
across the globe (Connor 1994), nationalism as a political principle may imply dangerous changes to the status quo. It tends to advocate a program of identity-homogenous state populations, when demographic realities are more complex. In a worst case, ethnic cleansing or forced assimilation might be invoked according to its mandate. Efforts to block immigration in order to preserve the status quo of a national majority also follow this logic of homogeneity.

Either populism or nationalism can form the content for identity-based parties. However, ethnic, national and religious parties might be linked to a majority or a minority, and indeed may advocate minority interests (Csergő). But populist parties, by definition, are rooted in the identity of the majority. Majority identity parties may portray themselves as advancing the rights of majorities at the expense of minorities. Those parties with a project of homogenizing the state may go so far as to take on an active program of eradicating others. The particular definition of the boundaries around "the people" to the exclusion of "others" has crucial implications (Mudde 2007, Brubaker 2017). Frequent targets of this us-them framing have been Jews, Muslims, and Roma (Mudde 2007, Chapter 3). Populist rhetoric over the past few years has easily expanded to include immigrants as target Others, and to describe their presence or arrival as a "crisis," a useful rhetorical device for nationalist or populist elites to mobilize populations (Moffitt 2016, Brubaker 2017).

Can this tendency to quash minorities mean that populism and nationalism abhor pluralism? This question is a debate within the literature on populism. For Jan-Werner Müller, populism is not only anti-elitist, but also inherently anti-pluralist. In Müller's logical formation, because populist leaders claim that only they can represent the people, other potential leaders or movements must be illegitimate (Müller 2017, 20, Gidrón and Bonikowski 2013). This emphasis on the potential for anti-pluralism is not shared by Mudde and others. However, Mudde does note that reasons for supporting populism can vary greatly among individuals (2007, 225-29), so anti-pluralist tendencies might perhaps vary by individual. The notion of the political legitimacy of one "pure" group at the expense of others evokes the logic of Gellner's nationalism (1983) - that the nation and the state should be congruent, with members of other nations excluded (also in Connor 1994).

For those who prioritize individual equality across groups, the exclusionary aspect of populism and nationalism is worrying. But if one prioritizes popular engagement, populism has some advantages from the perspective of democratic theory, advantages it shares with nationalism. As outlined by Kaltwasser (2014), populism can address two problems of procedural democracy as formulated by Robert Dahl. First, it proposes a means to designate a boundary around The People in the polity - whatever one might think of that boundary. Second, it suggests a resolution to the tension between constitutions and popular sovereignty, usually choosing the latter (Kaltwasser 2014, 472-77 and 479-83). The romance of a common collective identity to counter lonely 
individualism gives identity politics successful appeal. Both nationalism and populism share this claim to offer something more than individualistic liberalism (Csergő 2018) or technocratic rule. In the uncertain early years of post-communism, nationalism served as a useful kind of "ideological legitimation" for politicians to make appeals to publics unused to democratic practices (Tismaneanu $1998,7)$.

As mentioned above, populism has re-emerged in a context in which it seems that longstanding parties have lost meaning for many citizens, and in which citizens might be drawn to new party challengers (Katz and Mair 2009, Katz 2013, Kriesi 2014, 368). For Kriesi, economic globalization and supranational structures such as the European Union magnify these conditions of distance from the people, producing a sense that parties are structures without participants - or structures that have been hollowed out. This empty center in traditional parties draws citizens to support alternative political groups (2014). Populism's emphasis on The People also evokes a link to the romantic aspects of popular sovereignty, a move away from the (boring) pragmatism that can otherwise dominate politics (Canovan 1999, Kriesi 2014). As described by Brubaker, populism involved an "antagonistic re-politicization" of what has become technocratic politics $(2017,364)$.

\section{Nationalism and Populism as Strategies}

When one looks closely at the ideologies filling this void, at several points nationalism and populism become indistinguishable, something Jenne calls "ethno-populism" (2018). For both Tismaneanu (1998) and Müller (2019), nationalism is a subset of populism, a means to add a content to populist movements that legitimizes them. Brubaker explains this conflation of populism and nationalism as a useful political strategy, a "practical resource" used by elites $(2019,15)$. For Müller, writing about contemporary politics, "the leaders described as 'nationalists' are better understood as populist poseurs who have won support by drawing on the rhetoric and imagery of nationalism" (2019). Once in power, they use nationalist gestures to obscure the fact that they are not actually working to give back control to the people as promised (2019). In 1998, Tismaneanu had outlined "populist nationalism" as "the strongest ideological alternative to liberalism" $(1998,155)$, and a means to address popular demands for "protection from the drastic changes imposed by political and economic modernization" $(1998,73)$. Identity-based appeals can provide reassurance for populations reeling from economic and/or cultural uncertainty. This need for reassurance becomes a resource for would-be savvy elites.

As a means to explain the Balkan wars of the 1990s, the field of International Relations (IR) began to favour a premise that elites actively manipulate populations using nationalism, in order to gain power in these new democracies (Snyder and Ballantine 1996, Snyder 2000). In these accounts, 
elites are often rational and strategic about their deployments of nationalism, rather than true believers. The mass response is assumed to be based on a kind of collective psychology, but remains under-theorized (Stroschein 2012).

Deeper examinations of populism fill in some of these psychological and performative elements. Moffitt describes populism as a "political style" used by elites that is especially successful in the global context of new media technologies. The global reach of social media, and the way its content might be manipulated, provides a useful explanation for what seems to be a simultaneous increase of populist movements worldwide $(2016,10)$. The social media landscape amplifies simple rhetorical appeals, and rewards elites who can expertly combine their rhetoric with an entertainment aspect (Brubaker 2017). For Brubaker, the weakening of traditional parties sets a stage for elites to make direct appeals to "the people," a system context that combines with new media to further augment these rhetorical advantages. He notes that a successful rhetorical populist style has some common elements across various elites: "The populist style performatively devalues complexity through rhetorical practices of simplicity, directness, and seeming self-evidence, often accompanied by an explicit anti-intellectualism"[....]"Populists not only criticize the rules governing acceptable speech: they relish violating those rules" $(2017,367)$. Very similar observations might be made of nationalist rhetoric, particularly the speaking style used by Milošević during the 1990s.

Even if the precise content of populism and nationalism might differ, it is the political style they share that is operative in mobilizing publics. For this reason, it is worth turning our attention away from debates on this content, and focus on the dynamics of this political style and how it interacts with particular rituals, such as patriotic events or holidays, and with technology. A better understanding of the power of rhetorical appeals, combined with a better understanding of the dynamics of identity-based parties in political systems, will help us to better address their potential for both invigorating and threatening democracy.

\section{Conclusion: Understanding Parties and Identity Politics}

A full understanding of identity-based parties requires a focus on both the forms by which they navigate electoral and party systems, and the content of their rhetorical appeals to publics. In this review piece, I have outlined how the form of majoritarian electoral systems might provide an advantage to extremist elites if they manage to take over one of the large parties that these systems support. I have also indicated how the lack of a no confidence vote mechanism in presidential systems such as the US might help entrench extremist elites. This potential weakness has also made a recent appearance in the UK, where the Fixed-Term Parliaments Act (FPTA) of 2011 has constrained the mechanism of a no confidence vote. In terms of content, populism and nationalism 
might draw differing boundaries to include or exclude perceived elites. However, they can otherwise align in terms of their stances against Others, as well as against individualistic or technocratic stances that may fall under the label of "liberalism." Nationalism and populism are not simply ideologies, but can be used as strategies by elites who know how to successfully deploy these mobilizing rhetorical appeals.

Will these ideologies / strategies remain strong political forces over the long term? Their durability will likely depend on the degree to which they are solely the product of the machinations of cynical elites, or to which they represent actual societal cleavages, as in Lipset and Rokkan (1967). One of the difficulties in research on parties comes from a tension between general statements and local particularities. The content of The People in both nationalism and populism will vary not just across countries but within countries, and even within parties over time. If we are to conduct research with aim of making general statements, we can find some commonalities in 1) a focus on the forms in which identity-based parties navigate electoral and party systems, and 2) how the content of rhetorical appeals might work across settings. In this way, we might better understand where and when identity-based parties might be positive forces for citizen engagement, and when they might be dangers to defined Others and to their own democracies.

Disclosure. The author has nothing to disclose.

\section{References}

Achen, Christopher, and Larry Bartels. 2016. Democracy for Realists: Why Elections do no Produce Responsive Government. Princeton: Princeton University Press.

Almond, Gabriel, and James Coleman, eds. 1960. The Politics of the Developing Areas. Princeton: Princeton University Press.

Anderson, Benedict. 1983. Imagined Communities: Reflections on the Origin and Spread of Nationalism. New York: Verso.

Arendt, Hannah. 1951. The Origins of Totalitarianism. New York: Harcourt and Brace.

Berman, Sheri. 1997. "Civil Society and the Collapse of the Weimar Republic." World Politics 49 (3): 401-29.

Berman, Sheri. 2008. "Taming Extremist Parties: Lessons from Europe." Journal of Democracy 19 (1), 5-18.

Birnir, Jóhanna Kristin. 2007. Ethnicity and Electoral Politics. New York: Cambridge University Press. Bonikowski, Bart, Daphne Halikiopolou, Eric Kaufmann, and Mathijs Rooduijn. 2019. "Populism and Nationalism in a Comparative Perspective: A Scholarly Exchange." Nations and Nationalism 25 (1): 58-81. 
Brubaker, Rogers. 2017. "Why Populism?" Theory and Society 46: 357-85.

Brubaker, Rogers. 2019. "Populism and Nationalism." Nations and Nationalism.

https://onlinelibrary.wiley.com/doi/full/10.1111/nana.12522 (Early view, 29 April 2019).

Canovan, Margaret. 1999. "Trust the People! Populism and the Two Faces of Democracy." Political Studies 47 (1); 2-16.

Caramani, Daniele. 2004. The Nationalization of Politics. New York: Cambridge University Press.

Chandra, Kanchan. 2004. Why Ethnic Parties Succeed: Patronage and Ethnic Head Counts in India. New York: Cambridge University Press.

Chibber, Pradeep K., and Ken Kollman. 2004. The Formation of National Party Systems. Princeton: Princeton University Press.

Conner, Walker. 1994. "A Nation is a Nation, Is a State, Is an Ethnic Group, Is a...." In Conor, Ethnonationalism: The Quest for Understanding, 90-117. Princeton: Princeton University Press.

Cramer, Katherine. 2016. The Politics of Resentment: Rural Consciousness in Wisconsin and the Rise of Scott Walker. Chicago: The University of Chicago Press.

Csergö, Zsuzsa. 2007. Talk of the Nation: Language and Conflict in Romania and Slovakia. Ithaca: Cornell University Press.

Csergő, Zsuzsa. 2018. "Ethno-Nationalism and the Subversion of Liberal Democracy." Ethnopolitcs 17 (5): 541-45.

Dahl, Robert. 1971. Polyarchy: Participation and Opposition. New Haven: Yale University Press.

Dahl, Robert. 1989. Democracy and Its Critics. New Haven: Yale University Press.

Diamond, Larry. 1993. "Three Paradoxes of Democracy." In The Global Resurgence of Democracy, edited by Larry Diamond and Marc Plattner, 95-107. Baltimore: The Johns Hopkins University Press.

Diamond, Larry, and Marc Plattner, eds. 2006. Electoral Systems and Democracy. Baltimore: The Johns Hopkins University Press.

Downs, Anthony. 1957. "An Economic Theory of Political Action in a Democracy." Journal of Political Economy 65 (2): 135-50.

Gellner, Ernest. 1983. Nations and Nationalism. Ithaca: Cornell University Press.

Gidrón, Noam, and Bart Bonikowski. 2013. "Varieties of Populism: Literature Review and Research Agenda," Harvard University, Weatherhead Center for International Affairs. Working Paper, no. 130004, 2013. https://scholar.harvard.edu/files/gidron bonikowski populismlitreview 2013.pdf (Accessed February 16, 2019).

Goodwin, Matthew, and Oliver Heath. 2016. "The 2016 Referendum, Brexit and the Left Behind: An Aggregate-Level Analysis of the Result." The Political Quarterly 87 (3), 323-32.

Gormley-Heenan, Cathy, and Roger Mac Ginty. 2008. "Ethnic Outbidding and Party Modernization: Understanding the Democratic Unionist Party's Electoral Success in the Post-Agreement Environment." Ethnopolitics 7 (1): 43-61. 
Greenfeld, Liah. 1993. Nationalism: Five Roads to Modernity. Cambridge, MA: Harvard University Press.

Haughton, Tim, and Kevin Deegan Krause. 2015. "Hurricane Season: Systems of Instability in Central and East European Party Politics." East European Politics and Societies and Cultures 29 (1)61-80.

Horowitz, Donald. Ethnic Groups in Conflict. 1985. Berkeley: University of California Press.

Huntington, Samuel. 1968. Political Order in Changing Societies. New Haven: Yale University Press. Institute for Democracy and Electoral Assistance (IDEA). 2005. Electoral System Design: the New International IDEA Handbook. https://www.idea.int/publications/catalogue/electoral-system-designnew-international-idea-handbook. (Accessed February 16, 2019).

Inglehart, Ronald. 1971. "The Silent Revolution in Europe: Intergenerational Change in PostIndustrial Societies." American Political Science Review 65 (4): 991-1017.

Inglehart, Ronald, and Pippa Norris. 2017. "Trump and the Populist Authoritarian Parties: The Silent Revolution in Reverse." Perspectives on Politics 15 (2): 443-54.

Jenne, Erin K. 2018. "Is Nationalism or Ethno-Populism on the Rise Today?" Ethnopolitics 17 (5): 54652.

Kaltwasser, Cristóbal Rovira. 2014. "The Responses of Populism to Dahl's Democratic Dilemmas." Political Studies 62 (3): 470-87.

Kann, Robert, and Zdeněk David. 1984. The Peoples of the Eastern Hapsburg Lands, 1526-1918. Seattle: University of Washington Press.

Katz, Richard, and Peter Mair. 2009. "The Cartel Party Thesis: A Restatement." Perspectives on Politics 7 (4): 753-66.

Kitschelt, Herbert. 1992. "The Formation of Party Systems in East Central Europe." Politics and Society 20 (1): 7-50.

Kostovicova, Denisa. 2019. Comment on roundtable, "Thirty Years Since 1989: Europe Still Divided?" CEEISA-ISA Joint International Conference, University of Belgrade, 17 June 2019.

Kreisi, Hanspeter. 2014. “The Populist Challenge." West European Politics 37 (2): 361-78.

Laakso, Markku, and Rein Taagepera. 1979. "'Effective Number of Parties:' A Measure with Application to West Europe." Comparative Political Studies 12 (1): 3-27.

Levy, Jacob T. 2017. "The Party Declines," Niskanen Center Blog, 18 January. https://niskanencenter.org/blog/the-party-declines/. (Accessed February 16, 2019).

Lijphart, Arend. 1986. "Degrees of Proportionality of Proportional Representation Formulas." In Electoral Laws and Their Political Consequences, edited by Bernard Grofman and Arend Lijphart, 17079. New York: Agathon Press.

Lijphart, Arend. 1993. "Constitutional Choices for New Democracies." In Larry Diamond and Marc Plattner, The Global Resurgence of Democracy, edited by Larry Diamond and Marc Plattner, 146-58. Baltimore: The Johns Hopkins University Press.

Lijphart, Arend. 1999. Patterns of Democracy: Government Forms and Performance in Thirty-Six Countries. New Haven: Yale University Press. 
Linz, Juan. 1975, 2000. Totalitarian and Authoritarian Regimes. Boulder: Lynne Reiner Publishers. Lipset, Seymour, and Stein Rokkan. 1967. Party Systems and Voter Alignments: Cross-National Perspectives. New York: The Free Press.

Mair, Peter. 2013. Ruling the Void: The Hollowing of Western Democracy. London: Verso.

Mason, Lilliana. 2018. Uncivil Agreement: How Politics Became Our Identity. Chicago: University of Chicago Press.

Moffitt, Benjamin. 2016. The Global Rise of Populism: Performance, Political Style, and Representation. Stanford: Stanford University Press.

Mudde, Cas. 2004. "The Populist Zeitgeist." Government and Opposition 39 (4): 541-63.

Mudde, Cas. 2007. Populist Radical Right Parties in Europe. New York: Cambridge University Press.

Mudde, Cas. 2019. "Why Copying the Populist Right Isn't Going to Save the Left," The Guardian, 14 May.

Müller, Jan-Werner. 2014. "The Party's Over," review of Peter Mair's Ruling the Void. London Review of Books 36 (10), 22 May: 35-37. https://www.Irb.co.uk/v36/n10/jan-werner-muller/the-partys-over (Accessed February 16, 2019).

Müller, Jan-Werner. 2017, What Is Populism? New York: Penguin.

Müller, Jan-Werner. 2019. "False Flags: The Myth of the Nationalist Resurgence." Foreign Affairs, March/April.

O'Dwyer, Conor. 2014. "What Accounts for Party System Stability? Comparing the Dimensions of Party Competition in Postcommunist Europe." Europe-Asia Studies 66 (4): 511-35.

Pop-Eleches, Grigore. 2010. "Throwing out the Bums: Protest Voting and Unorthodox Parties after Communism." World Politics 62 (2): 221-60.

Pirro, Andrea L. P. 2018. "Understanding Populism: What Role Do Crises Play in the Growth of Euroskepticism?," LSE EUROPP Blog, 6 June, http://blogs.Ise.ac.uk/europpblog/2018/06/06/understanding-populism-what-role-do-crises-play-inthe-growth-of-euroscepticism/. (Accessed February 16, 2019).

Reynolds, Andrew, Ben Reilly, and Andrew Ellis. 2005. Electoral System Design: The New International IDEA Handbook. Institute for Democracy and Electoral Assistance:

https://www.idea.int/publications/catalogue/electoral-system-design-new-international-ideahandbook. (Accessed 25 June 2019).

Roodujin, Matthijs, and Tjitske Akkerman. 2017. "Flank Attacks: Populism and Left-Right Radicalism in Western Europe." Party Politics 23 (3): 193-204.

Rosenbluth, Frances McCall, and lan Shapiro. 2018. Responsible Parties: Saving Democracy from Itself. New Haven: Yale University Press. 
Saideman, Steve. 2015. "Why Do We Care about Ethnic Outbidding?” Saideman's Semi-Spew (Blog), 9 December. http://saideman.blogspot.com/2015/12/why-do-we-care-about-ethnicoutbidding.html (Accessed 25 June 2019).

Sartori, Giovanni. 1976. Parties and Party Systems: A Framework for Analysis. New York: Cambridge University Press.

Sartori, Giovanni. 1994. Comparative Constitutional Engineering: An Inquiry into Structures, Incentives, and Outcomes. New York: New York University Press.

Schmitter, Philippe, and Terry Lynn Karl, "What Democracy Is... And is Not." 1993. In The Global Resurgence of Democracy, Larry Diamond and Marc Plattner, eds, 39-52. Baltimore: The Johns Hopkins University Press.

Schwedler, Jillian. 2011. "Can Islamists Become Moderates? Rethinking the Inclusion-Moderation Hypothesis." World Politics 63 (2): 347-76.

Sikk, Allan. 2009. "Parties and Populism." Centre for European Politics, Society, and Integration (CEPSI), School of Slavonic and East European Studies (SSEES), UCL. Working Paper 2009-2. http://discovery.ucl.ac.uk/1400395/1/PartiesandPopulism.pdf

Sikk, Allan. 2011. "Newness as a Winning Formula for New Political Parties," Party Politics 18 (4): 465-86. (Accessed February 16, 2019).

Smith, Anthony D. 1986. The Ethnic Origins of Nations. Cambridge: Blackwell Publishers, 1986.

Snyder, Jack, and Karen Ballentine. 1996. "Nationalism and the Marketplace of Ideas." International Security 21 (2): 5-40.

Snyder, Jack. 2000. From Voting to Violence: Democratization and Nationalist Conflict. New York: W. W. Norton.

Stanley, Ben. 2008. "The Thin Ideology of Populism." Journal of Political Ideologies 13 (1): 95-110.

Stokes, S. C. 1999. "Political Parties and Democracy." Annual Review of Political Science 2: 243-67.

Stroschein, Sherrill. 2012. Ethnic Struggle, Coexistence, and Democratization in Eastern Europe. New York: Cambridge University Press.

Stroschein, Sherrill. 2016. “Ethnic Conflict: Looking Inside Groups." Ethnopolitics 16 (1): 74-81.

Stroschein, Sherrill. 2017. "Tempo, Protest, and Emergency Ethnography in the Trump Moment." Duck of Minerva (Blog), 31 January. https://duckofminerva.com/2017/01/tempo-protest-andemergency-ethnography-in-the-trump-moment.html (Accessed 20 August 2019).

Tilly, Charles. 2003. The Politics of Collective Violence. New York: Cambridge University Press.

Tismaneanu, Vladimir. 1996. "The Leninist Debris or Waiting for Perón." East European Politics and Societies 10 (3): 504-35.

Tismaneanu, Vladimir. 1998. Fantasies of Salvation. Princeton: Princeton University Press.

Van Cott, Donna Lee. 2005. From Movements to Parties in Latin America. New York: Cambridge University Press. 
Vasiliopolou, Sofia. 2009. "Varieties of Euroskepticism: The Case of the European Extreme Right." Journal of Contemporary European Research 5 (1): 3-23.

Wimmer, Andreas. 2019. "Why Nationalism Works, And Why it Isn't Going Away." Foreign Affairs, March/April.

\footnotetext{
${ }^{1}$ Parties also exist in authoritarian systems as a functional means to organize publics, an aspect not considered here.

${ }^{2}$ A useful overview of electoral systems appears in Reynolds et al 2005.

${ }^{3}$ Assuming single-member-districts. Other types of systems may feature multi-member districts. It should be noted that the presence of regional parties might produce different strong parties in different areas, such as the Scottish National Party in Scotland. Majoritiarian systems with strong regional parties, like the UK, might thus exhibit a weakened version of this rule.

${ }^{4}$ Seats in parliaments are filled with a formula to translate the votes into seats (Lijphart 1986).

${ }^{5}$ Another means to count parties is the "effective number of parties," a formula developed by Laakso and Taagapera (1979), in which counts reflect both the number and size of the parties by their ratios in parliament. ${ }^{6}$ As of August 2019. Given the volatile nature of current UK politics, this figure could change in the event of a surprise election.

${ }^{7}$ It is worth note that the power of referenda, such as the 2016 referendum on Brexit, has not been resolved relative to the perceived dominance of parliamentary sovereignty.

${ }^{8}$ I am grateful to Erin Jenne for conversations on this point.
} 